\title{
Efficiency in Banking: Analysis of Factors Affecting the Internal Audit Effectiveness in Ghana
}

\author{
Ebenezer Nana Yeboah \\ School of Accounting, Zhongnan University of Economics and Law, Wuhan 430072, China
}

\begin{abstract}
Although organizational internal control is for the purpose of ensuring effectiveness and efficiency of operational activities, trustworthiness of financial data amidst compliance with auditing standards which have been instituted into the mundane activities of banks in Ghana, many banks still have difficulties in recovering facilities which are granted to customers after expiry. This study assesses the effectiveness of internal auditing in rural banks in the Central Region of Ghana. Adding to the body of knowledge, the paper argues that in spite of the instituting of internal audit units in various rural banks, the issue of default of bank facilities is gradually destroying most gains and also crippling business opportunities. Methodologically, the paper adopts a descriptive survey where primary and secondary data are effectively utilized. The findings of the study revealed that the default in rural banks facility recoveries are accorded to the fact that most recommendations cited by internal auditors are not applied. The study findings also showed that most internal auditors lack the necessary in training to be updated on the job in order to make them function at their full human resource capacity while other bank operating units rip the internal auditor of privacy and independence. The study recommends among others that prior to the findings of the study, internal audit findings should be used as a gauge to facilitate banking operations while implementing suggested recommendations so as to achieve set targets of rural banks. Furthermore, the banks should endeavor to periodically offer training programs for internal audit staff to enlighten and update them on the ethics of the auditing profession.
\end{abstract}

Keywords: Internal Audit Effectiveness, Rural Banks, Ghana

DOI: $10.7176 /$ RJFA/10-4-05

\section{Introduction}

On the recent, internal audit is regarded as a value adding service to any organization (see Al-Twaijry et al., 2003; Arena and Azzone, 2009; Bou-Raad, 2000; Enyue, 1997; Goodwin, 2004; Moeller, 2005; Roth, 2000, 2002). According to the Global Institute of Internal Auditors (IIA), internal auditing is an independent, objective assurance and consulting activity designed to add value and improve an organization's operations thereby helping an organization accomplish its objectives by bringing a systematic, disciplined approach to evaluate and improve the effectiveness of risk management, control, and governance processes.

Although organizational internal control is for the purpose of ensuring effectiveness and efficiency of operational activities, trustworthiness of financial data, compliance with auditing standards which have been instituted into the mundane activities of banks in Ghana, many banks still have difficulties in recovering facilities which was granted to customers after expiry. The sky high challenge of default of bank facilities is gradually destroying most gains and also crippling business opportunities. Internal control problems are a common place in the banking industry, and have allowed rogue traders to cause huge financial losses to banks. In 2012, HSBC the largest financial institution in Europe, said they have poor money laundering controls and as a result was fined $\$ 1.9 \mathrm{~b}$ after U.S Senate investigations (BBC, 2012). Addo (2001) reported that the banking sector in Ghana had some bank failures in the early 2000 "s, thus, the "collapse' of the Ghana Co-operative Bank, and also Bank for Housing and Construction. Addo also stated that the failure cost incurred by the Ghana government amounted to Ghc1.25 billion, in liquidation due to poor internal control structures and systems. This would mean that internal auditing systems and activities are of importance in every organization, its collapse would lead to failure of organizations . According to Asiedu-Mante (2011), rural banks in Ghana have a trend of mismanagements of fund, data being lost, money disbursements which have led mergers and acquisition, and even the collapse of some rural banks. From the foregoing discussion, it is evident that the internal auditors within the various rural banks are not working effectively as they should. Despite these, there hasn't been any research work done to investigate to know the reasons behind this entire problem that the rural bank in Ghana are facing.

Adopting the methodology of a descriptive statistical design consisting of both primary and secondary data sources, the study sets to examine the efficiency of internal audit systems in the banking sector using rural banks in the central region of Ghana as a case study. In terms of organization, the study is structured into five sections. Following the introduction in section one is the review relevant literature on internal audit captured in section two which discusses the theoretical and empirical framework relevant to internal audit. Section three explains the methodology utilized in carrying out the research. Section four presents the data, analysis and discussion of findings, while section five presents the conclusion and recommendations. 


\section{Literature Review}

\subsection{Theoretical Perspectives}

Theories are an important part of framework used to organize specific social phenomena. To this effect, the study adopts the two main related theories namely, agency and institutional theories. These are briefly presented below.

\subsubsection{The Agency Theory}

Agency theory is important in the operations of organizations over the years. Agency theory talks about the relationship between principals and agents in business. In the view of Meckling and Jensen (1976), agency relationship is a bond under which an individual (that is the principal(s)) engage another individual (the agent) to perform some service on his or her behalf which involves some delegation of decision making authority to the agent. Thus, for the internal audit to be effective there is need for not only their independence but also the top management support. From an agency viewpoint, the significance of strong governance stems forms the necessity to place the interests of management with other stakeholders in the corporate organization so as to decrease agency expense and increase the internal audit department effectiveness structures (Mitnick, 2006). Many corporate governance systems can be used to monitor the management's behavior and these include independent directors on the board, an independent board chair, effective independent audit committee, and both external and internal audit. Davidsonm et al. (2005) describes the complex interactions between these governance systems as the corporate governance mosaic.

\subsubsection{Institutional theory}

Institutional theory proposes that the survival of an organization depends not only on achieving production efficiency but also on its conformity to an acceptable societal norms and practice (DiMaggio and Powell, 1983). Institutional theory explains how organizational practices and structure are formed through changes cause by institutional pressures. Institutional theorists, mostly consider organizations as members of an organizational field, which comprises several organizations or industries that are interrelated in some way. This interrelation leads organizations to influence others (Mihret and Woldeyohnnis, 2008). O'Leary and Stewart, (2007), suggested that organization in a structured field respond to an environment that consists of other organizations that respond to their environment. As a result, institutional pressures and a desire to categorize themselves with some organizations in a similar environment, organizations tend to adopt similar characteristics. According to institutional theory by Fogarty and Roger (2005), an organization is designed and functions to meet social expectations so much as its operations are visible to public. Therefore organizational internal operations, which are often complex and difficult to identify, may take second place to the issue of external legitimacy. It is suggested that the external image of the organization might be loosely close with its operating processes and the kind of technology it adopts. Fogarty and Rogers (2005) asserted that the contribution of institutional theory is in the insight that the actual accomplishments of organization and what its structure suggests should accomplish are often different. The institute operates with internal processes which are not really visible to those external to it, while other structures maintained for outsiders do not significantly contribute to output. Fogarty (1996) highlighted that critical observation by outsiders can be avoided if the right structures and systems are adopted by organizations. Weakness in technological coupling enables organizations to show success in external problems whilst allowing flexibility in operational processes. Thus the institutions should be ready to meet the high cost of adopting various technologies in the internal audit section and to see to it that the staff are trained in order for the department to operate efficiently.

Subsequently, decoupling may occur when organizations display to the world (the business world), that they are operating in a perceived manner internally, when actually the external environment view it that they are in fact falling short of those expectations (Meyer and Rowan 1977). IA research considers Institutional theory suitable for many reasons. Primarily, the theory comprises IA practices which are part of organizational phenomena. Then, it aids to explain organizational phenomena without having in mind a limited set of organizational goals unlike agency and transaction cost theories, which are both predicated on the assumption to maximize the wealth of shareholders. Moreover, it could aid audits research in a developing country where the equity market is underdeveloped (Mihret et al., 2008). Earlier study also recommended that institutional theory has validity in IA research, both in some developing countries (Al-Twaijryet al., 2004) and developed countries (Arena and Azzone, 2007).

Based on the above discussion, institutional theory is considered to be the utmost relevant for this study and, more precisely, it is considered to be appropriate for IA research. Marxist theory explains that the demand for IA could support institutional theory's implication for IA practice.

\subsection{Effectiveness of internal Audit on Financial Performance}

An effective and efficient internal audit function must have a good impact on the control environment and a successful design and operation of internal control of an organization. Audit committee's responsibility is to evaluate how effective internal audit function's work. This assessment must be perform regularly. Other forms of evaluation of internal audit must also include an assessment of internal audit's objectivity and independence. 
Internal audit must review their plans regularly and the audit committee also need to reflect on how internal audit has delivered and compare their work with the plan, and also the quality of those results.

Internal audit effectively has a double reporting relationship. The first is where the head of internal audit unite has to reports to executive management (which is the CEO) to assist and help them by establishing some form of direction, support, and administrative matters. The second is, head of internal audit also report to audit committee for some strategic and good direction, accountabilities and also for reinforcement. Therefore the committee need to see to it that external audit functions are very effective. It must ensure internal audit have a direct way of communication and support from the committee. The committee must also consider and take into account the resources that are dedicated to internal audit function. They need to see to it as to whether these resources can enable internal audit to perform and deliver on its audit plan. Particularly, attention must be focus on this during organizational change and restructuring. Self-assessment by the leader of internal audit unit is very important and useful tool for assessment. However, this mustn't be the only means of assessing how effective internal audit unit could be. The committee must see to it that, it has its own conclusions based on their experience and contact with internal audit as well as opinions of others such as CFO, heads of various divisions and also the external audit. In evaluating the work concerning the internal audit, audit committee must review the annual plan work concerning internal audit, receive periodic reports on the outcome of the work by internal auditors and monitor management's responsiveness to internal auditor's result or findings and their recommendations

Some school of thought suggest that risk management, effective internal control system, and audit experience, relationship between internal and external auditors and performance management are factors which have effect and influence on effectiveness of internal audit.

\subsection{Challenges Facing Internal Auditors.}

In Poland, Bielińska-Dusza (2011) studied on the functions of internal auditors in companies. The study show us a number of barriers reducing the efficiency of internal audit, and audit functions as an instrument for company improvement. The study highlighted these barriers: lower level of cooperation between the auditors and other workers of the company; and difficulties concerning both audit planning process and method of its implementation. The problem that came with how to implement these audit method included lack of time, resistance of employees towards changes, organizational difficulties, information disturbances and work overload among auditors. Auditing is normally a control over managers and also a control over controls. This understanding of auditing concept assist the argument that the function must be independent of managers. Ideally, some of those responsibility of internal auditing must be to audit top managers' activities. The approach of auditing top managers' strategic management activities is one way in which an auditor could add value and contribute to improve performance of an organization. However, it must be taken into consideration that auditing top managers' activities is a hot issue facing the profession today (Barlow et al., 1997)

According to Mebratu (2012), organizational independence, formal mandate, unrestricted access to information, sufficient funding, competent leadership, competent staff, support of management, and professional audit standards to achieve the risk management, governance functions and controls as stated under (IIA, 2006) were considered challenges. These elements which determine how effective audit work in public sector governance in Ethiopia were known to be the various challenges facing the internal audit. The elements were not evident in their government so internal audit was seen not to be effective.

The duty of internal audit must be an independence and objective function. Yet, this independence can be compromised, particularly where reporting lines are through operational areas which they are required to review and report on. To be able to work as an independent section has been a long-standing challenge to internal auditors and their profession. The rise in corporate governance has made this challenge to receive renewed attention. The basic role of internal auditors give them difficulties and as such does not make them work as an independent unite. For instance, the work of internal auditors is to give audit oversight for their organization together and also provide consulting services to management.

Managers are responsible for, among others things, identifying, managing and controlling the risk of not achieving departmental goals, i.e. risk management. Some of the managers' responsibilities is to ensure the achievement of their performance objectives. Fraud is one threat that could prevent a unit manager from achieving his performance objectives. Therefore, managers are the ones who are responsible for the prevention and detection of fraud. Managers do not, however, regard this as their responsibility and they expect the auditor to be ones responsible for that. (Barlow et al., 1997).

\subsection{Internal Audit Effectiveness}

This study is a very key issue globally. Several research have been done on this in different organizations and countries. Below is a review analysis on related extant literature.

Mihretet al. (2010) stated that the value-adding role of internal audit presumes that it is effective. In Saudi Arabian, Al-Twaijryet al. (2003) a study was done on the development of internal audit in the county's corporate 
sector with the use of the institutional theory perspective, and taking 135 business organizations listed on the Saudi's Stock 50 Exchange. The study was conducted by the use of questionnaires and interviews to test the extent of compliance of internal audit practices with ISPPIA in terms of quality of audit staff; quality of audit work; an appropriate corporate environment; and support of top management to examine the audit effectiveness. The results of this study showed that internal audit in the country's corporate sector is very ineffective and it is not a value adding service to organizations. The study's results also showed that managers sometimes do not implement the recommendation of internal audit departments. Further, the results indicated that audit may sometimes be decoupled, that is, the function may not work in compliance with ISPPIA despite stakeholder's expectations of compliance.

Goodwin (2003) did a study in Australia and New Zealand. The study reported that internal auditors in public sector are less likely to report to head of financial affairs than those in private sector. Although these two sectors often outsource internal audit work, public sector institutions are most likely to use an external auditor for these services. Moreover, it doesn't seems to be any major difference between internal auditors in those two sectors in concerning their interaction with external auditors.

Yee et al. (2008) studied about the perception of Singaporean managers on internal audit practice. The overall findings were that 1) the internal audit section in Singapore is improving and has become an important part of organizations' structures as value adding service; 2) in general, managers are satisfied with internal audit; and 3) internal audit section can play a value adding role in modern organizations by expanding its scope of services to embrace operational areas. As Yee et al. explain, internal audit, may allow a company to improve its efficiency so that during times of economic downturn it is their competitors who suffer the greatest share of loss of surplusvalue and capital.

Effective internal audit unit plays a major role in helping the board to perform its governance responsibilities. The study of O'Leary, and Stewart (2007) used exploratory study; this was done by presenting the five ethical dilemmas for 66 internal auditors. For each case, a major element of corporate governance was operated so as to help its influence on ethical decision making. These were audit committee support; management truthfulness regarding different accounting policies; integrity of management in relation to pressure on internal audit; external auditor characteristics; and organizational code of conduct. The result was able to show the different ethical decision-making related to internal audit and corporate governance.

Keitany (2000) also studied on internal audit control section. A case of quoted companies ${ }^{e e}$ aimed to establish whether there was an adequate internal audit function which translates into a strong internal system that can be relied upon by external auditor. The study adopted an exploratory research design and the population was all companies active in the NSE and their external auditors. The sample was $100 \%$ of the population where basic data was collected using semi structured questionnaires with close ended questions. The data was analyzed using descriptive statistics which means, standard deviations and percentages. It was concluded that though the level of reliance of internal controls is not sensitive to the strengths of internal audit departments, companies should not do away with it. This is because as a management tool, it should help management in its daily operations and not necessarily of relevance to the external audit

Kibet (2008) in his research focused on exploring the role and use of internal audit functions to promote better corporate governance in public sector enterprises and the challenges faced by internal auditors in SOEs. The research followed an exploratory research design and the population comprised of all SOEs with government equity of over 50\% located in Nairobi. Questionnaires was used to collect data and then most of the respondents were heads of internal audit departments. Some were also the just normal audit members and staff of the organization. Data collected was analyzed using the SPSS and it output was presented in frequency distribution tables, pie and bar charts. The study concluded that internal audit function was effective and played an important and major role in corporate governance.

Ramachandran et al. (2012) examined how internal audit work in Tanzanian commercial banks operate since the work is now mandatory requirement as per Banking and Financial Institutions Act 2006. Results deliberated that, the risks management and corporate governance activities of internal auditors are brought together as statutory obligations and does not give additional value to stakeholders. The study also asserted that internal auditing in the country's commercial banks is still using the conservative approach which is basically concerned with compliance and monitoring rather than adopting value added methodology. The study is important to the agency theory because it help avoid situations where resources and fund are being use on activities which doesn't give value to stakeholders.

\subsection{Rural and Community Banking in Ghana (RBCs)}

They (RBCs) are commercial banks which operate under the Banking Law, just that foreign exchange operations are not among its banking activities. Rural and Community bank was first established in Ghana in 1976 to give banking services to people in those rural areas, and also provide credit to small-scale farmers and businesses. Another reason was to also support development project. The first one was in Agona Nyakrom in Central Region 
(Huq, 1989). In many rural communities, before rural banking came up, they didn't have any better secured or safe place to run savings and payment work. Most people in those areas end up keeping their own money.

Most of the banks are owned and manage by the people leaving in the community. They get their customers from their local area, and the minimum capital requirement is less compared to that of the traditional banks. Nair and Fissha, (2010) reported Rural and Community banks are owned by individual who are residents of those communities. The bank has board of directors (BoD) who are responsible for its strategic governance. Their key responsibilities include (1) appraisal and approval of loan applications and to ensure its repayment; (2) monitoring the financial performance of the bank; (3) providing strategic guidance to management; and (4) supervising the management.

In the 1980s the numbers grew swiftly, this was because the services the government introduced to check cash payment to cocoa farmers (Anin, 2000). By the end of 2016, there were 137 licensed rural banks in operation of which 21 of them are located in the Central Region alone (Bank of Ghana, 2014). The Central Region Rural Banks which are part of Rural Community banks are regulated by Ghana's Central Bank, the Bank of Ghana, and form part of the country's regulated financial sector. Formal financial services in rural areas are largely provided by rural community banks and they represent about half of the total banking sector in Ghana (IFAD, 2008). Due to the nature of rural banks services the Apex Bank is delegated by Bank of Ghana to provide unique services specifically to improve quality and scope of products offered and also performs important supervisory functions to Rural Community banks.

The main services that rural banks deliver are savings; credit; and money transfers and payments. Rural banks savings service include susu deposit, regular savings accounts, current accounts, and fixed or time deposits. These accounts are small in size and short term with low interest rate. The credit products offered by Rural Community banks are personal loans, susu loans, microfinance loans, salary loans, and over-draft facilities. Rural banks loans mostly are used for agriculture, cottage industries and trading. Rural banks also provide money transfer and payment services to their clients in collaboration with the ARB Apex Bank. Both local and international money transfers are services performed by Rural Community banks. Among others are, Western Union, Money Gram, and Vigo.

The core management staff of a classic Rural Community banks is typically composed of a CEO who is responsible for daily management of the bank; an internal auditor in charge of internal control measures who reports to the Board of directors; a finance officer; and credit and project officers (in charge of microfinance operations). Moreover almost all rural banks have one or more branches and each is staffed with branch manager, an accountant, credit officers, clerks, and cashiers.

\section{Research Methods}

This section describes the research design, the population, the sample and sampling procedure. In line with Darko, S. et al. (2018), the study employed survey and descriptive technique. The major techniques or tools used to collect data in descriptive survey designs are the questionnaire, interview and observation (Bell and Bryman 2007). Descriptive survey design was appropriate for the study, since it allowed the researcher to collect data in analysing internal audit effectiveness. Questionnaires were the main instruments used to collect data from accountants, internal auditors, System Administrators, Operation Managers, Human resource and administration and credit departments of rural banks due to the fact that they are people whose work are in line with the audit. In selecting the sample size of staff and workers alike for the survey, the Slovin's sampling method was used.

The formula is presented as;

$\mathrm{n}=\mathrm{N} /[1+\mathrm{N}$ (e) 2] (where $\mathrm{n}=$ sample size; $\mathrm{N}=$ sample frame; and $\mathrm{e}=$ margin of error/ confidence level).

As indicated above, a sample frame of 930 workers whose work are in line with audit unit was estimated. And a margin of error of $5 \%$ was used because of the convenient method adopted which reduced the possibility of nonresponse to the minimal level. Using the Slovin's formula the sample size for the study is computed as:

$\mathrm{n}=\mathrm{N} /=930 /=930 /=310$

The sample size of 310 staff whose work are related to the audit unit is considered from the various rural banks in the central region of Ghana.

The questionnaire was structured into two (2) sections. The first section has questions that are related to the respondents' general information. The questionnaires were set according to the objective of the study. On average, each section has nine questions with a combined close-ended. Under section one of the survey questionnaire, thus, the general respondents information section, the questionnaire has questions such as, age, gender, the length of years' of service, department and educational level. Under the second section of the questionnaire, questions concerning the role of internal auditors were asked, questions on how they perceive effectiveness of internal auditors, questions that relate to the roles of audit committee in the various banks and the final question was on the challenges facing the internal auditors in performing their duties. 


\subsection{Case of Institution under Study}

There are various rural banks in Ghana. This study was focused mainly on the rural bank in the Central Region. Ghana is mainly divided into Ten Region. Central Region is among the largest regions in Ghana. This study however is focused on Central Region of Ghana. There are twenty one (21) rural banks in the Central Region, being among the 137 licensed banks in the county as at January, 2017 (Bank of Ghana, 2017). These banks are to operate in line with the regulations of Bank of Ghana. The common department found in these banks are; internal audit, Information technology, accounts, operations, administration and credit. Most of the rural banks in Central Region have just one internal auditor who works in banks except for Kakum rural bank and Awutu Emasa rural bank. The justification for using banks in the Central Region was as a result of the poor performances and the collapse of some rural banks in the region on the recent.

\subsection{Hypothesis Development}

Figure 3.2: Hypothesis for the Study
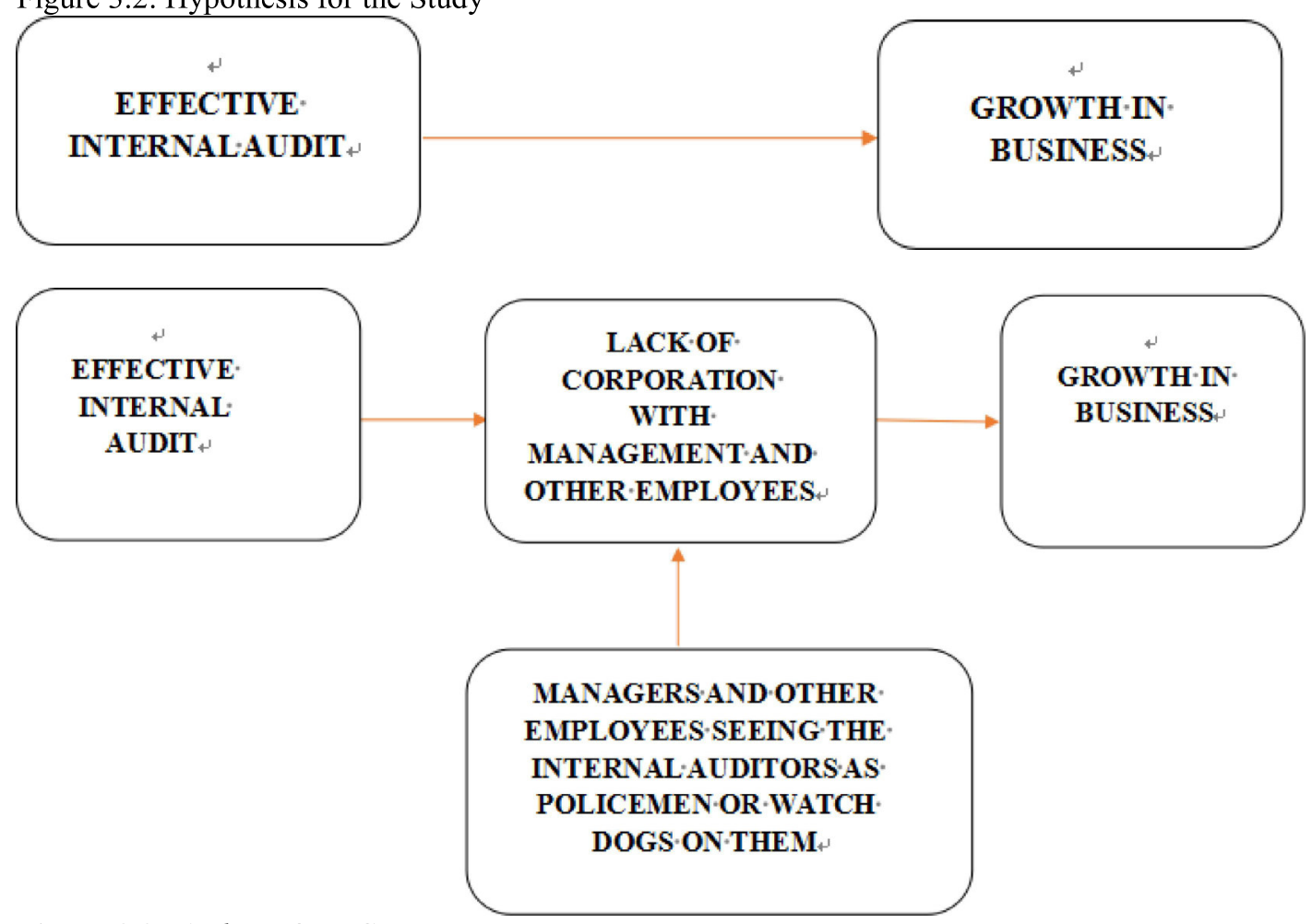

Figure 3.2: Authors Own Construction

From the above assertions, it could be seen that, all other things being equal, when internal audit is very effective, it will lead to growth in business (figure 3.2). This indicate that effective internal audit function in an organization can have a positive impact on the control environment and the effective design and operation of internal control, which will lead to growth in business.

However, what happens to the relationship between effective internal audit and growth in business when it is moderated by luck of corporation between internal auditors and management (and employees as well), as a variable? Will this lead to a positive or negative impact on the growth in business of the organization? This research will attempt to investigate this phenomenon and more, "with management and other employees seeing the internal auditors as policemen or watch dogs on them" as the Mediator variable to explain the possible outcomes. The findings of this study will bring into focus the possible impact of effectiveness internal audit functions on rural banks in the Central region of Ghana.

\section{Data Presentation, Analysis and Discussion of Findings}

This section presents data and analysis of the responses gathered from the field survey. In analysing the data with reference to the research objectives, percentage tables including figures to show a clear picture of the study's findings and their implications. The demographic of respondents was presented first which consisted of the gender specifics and the age distribution of respondents, followed by results from the field survey, which is analysed according to the study's objectives. 
4.1. Academic Qualification of Respondents

The analysis show that $16.86 \%$ were Secondary school holders, $29.41 \%$ were HND holders, $39.23 \%$ of those respondents are Degree holders, 6.86\% of respondents were Master's Degree holders, 7.84\% had professional qualifications. The academic qualifications of this respondent indicate that most of those respondent are educated staff, in the Rural Banks. This could influence the kind of services they provide in the rural banking sector.

Table 4.1: Academic Qualification

\begin{tabular}{|l|l|l|}
\hline Level & Number of Responses & Percentage (\%) \\
\hline Secondary & 52 & 16.66 \\
\hline HND & 91 & 29.41 \\
\hline First Degree & 121 & 39.23 \\
\hline Master's Degree & 22 & 6.86 \\
\hline Professional & 24 & 7.84 \\
\hline Total & $\mathbf{3 1 0}$ & $\mathbf{1 0 0 . 0}$ \\
\hline
\end{tabular}

Source: Field survey data, 2018

\subsection{Distribution of Respondents' Departments}

It was found that, $13.73 \%$ work in internal audit department, $30.40 \%$ were accounting staff, $5.88 \%$ were credit staff, $34.31 \%$ were operational staff, $3.92 \%$ were from the IT, and 7.84 percent were administration staff and a non-response of $3.92 \%$. This analysis shows that internal auditing function is highly recognized by the rural banking sector. This is because though the $13.73 \%$ seems to be small, it is shows good signs since some organizations may have audit staff of less than 5. Again all the departments are functional showing structured and organized nature of the rural banks.

Table 4.2: Distribution of Respondents' Departments

\begin{tabular}{|l|l|l|}
\hline Department & Number of Responses & Percentage (\%) \\
\hline Internal Audit & 43 & 13.73 \\
\hline Account & 94 & 30.40 \\
\hline Credit & 19 & 5.88 \\
\hline Operation & 106 & 34.31 \\
\hline IT & 12 & 3.92 \\
\hline Administration & 24 & 7.84 \\
\hline No response & 12 & 3.92 \\
\hline Total & $\mathbf{3 1 0}$ & $\mathbf{1 0 0 . 0}$ \\
\hline
\end{tabular}

\section{Source: Field survey data, 2018}

\subsection{Length of Service}

Using frequencies and percentages for the analysis, the results found that with respect to the length of service of the respondents, it was noticed that $47.10 \%$ had worked with their organization between $0-5$ years, $26.50 \%$ have worked for 6 - 10 years, $12.80 \%$ have worked for $11-15$ years and $9.8 \%$ that worked for $16-20$ years, $1.90 \%$ have worked for 21 and above and a non-response of $1.90 \%$. It can be notice that majority have worked with the rural bank for not more than 5 years. However combining the other ranges, greater of the employees have worked more than 6 years and this in effect means the rural banks have more experienced employees.

Table 4.3: Length of Service

\begin{tabular}{|l|l|l|}
\hline & Number of Responses & Percentage (\%) \\
\hline $\mathbf{0}-\mathbf{5}$ & 146 & 47.10 \\
\hline $\mathbf{6}-\mathbf{1 0}$ & 82 & 26.50 \\
\hline $\mathbf{1 1}-\mathbf{1 5}$ & 40 & 12.80 \\
\hline $\mathbf{1 6}-\mathbf{2 0}$ & 30 & 9.80 \\
\hline $\mathbf{2 1} \&$ above & 6 & 1.90 \\
\hline Non response & 6 & 1.90 \\
\hline Total & 310 & 100.0 \\
\hline
\end{tabular}

Source: Field survey data, 2018

\subsection{Position Held in Institution}

Results on the position held by the respondents showed that, $13.7 \%$ were managers, $49.0 \%$ were senior staff, and 
$37.3 \%$ were junior staff. Senior staff is with the greater number, followed by junior staff and the managers respectively. Thus most operational activities are carried out by the senior staff. Again it could be deduced that almost very rural bank a manager and or assistant who manage the entire activities of the bank.

Table 4.4: Position Held

\begin{tabular}{|l|l|l|}
\hline Position & Number of Responses & Percentage (\%) \\
\hline Manager & 42 & 13.7 \\
\hline Senior Staff & 152 & 49.0 \\
\hline Junior Staff & 116 & 37.3 \\
\hline Totals & 310 & 100.0 \\
\hline
\end{tabular}

Source: Field survey data, 2018

\subsection{The Role of Internal Auditors}

To be able to effectively and efficiently manage a business organization, internal auditing functions are vital in every business organization. This was done by taking all departments into consideration. In doing this, multiple respondent techniques was used. This technique allowed respondents to choose more than one answer from the options given. By so doing total of responses were more than 100 percent. The details are presented in Table 4.5

\section{Table 4.5: The Role of Internal Auditors}

\begin{tabular}{|c|c|c|}
\hline Roles of internal auditors & $\begin{array}{l}\text { Number of } \\
\text { Responses }\end{array}$ & $\begin{array}{l}\text { Percentage } \\
(\%)\end{array}$ \\
\hline Evaluate the adequacy of the company's system of internal control & 264 & 85.3 \\
\hline Examine the reliability of accounting information & 217 & 69.9 \\
\hline $\begin{array}{l}\text { Ensure compliance to policies, plans, procedures, laws and } \\
\text { regulations }\end{array}$ & 210 & 67.6 \\
\hline Review the systems used for safeguarding the company & 176 & 56.8 \\
\hline $\begin{array}{l}\text { Provide consultations for top management in regard to adequate } \\
\text { internal control system }\end{array}$ & 210 & 67.6 \\
\hline $\begin{array}{l}\text { Provide consultations for top management in regard to risk } \\
\text { management }\end{array}$ & 216 & 69.6 \\
\hline Appraise the effectiveness and efficiency of the resources employed & 264 & 85.3 \\
\hline $\begin{array}{l}\text { Responsible for following up and ensuring the corrective actions are } \\
\text { taken }\end{array}$ & 240 & 77.5 \\
\hline $\begin{array}{l}\text { Evaluate and improve the effectiveness of risk management, } \\
\text { control, and governance processes }\end{array}$ & 201 & 64.7 \\
\hline
\end{tabular}

Source: Field survey data, 2018

The table above shows that one major role of internal auditors is to evaluate adequacy of the company's system of internal control. This constituted $85.3 \%$ of the responses. It implies that most employees knows internal auditors are to assess all internal control practices like financial controls, operational controls and stores and inventory control. This role is in line with the finding of Kwon and Banks (2004) who stated that internal auditor is responsible to examine and report internally on the integrity of the firm's accounting and financial reporting systems.

Another major role of internal auditors was appraisal of effectiveness and efficiency of resources employed. This constituted $85.3 \%$ of the responses, it mean that employees understand that internal auditors are to see to it that resources are used very judiciously which is in agreement with (Hass). The responsibility of following up and ensuring the corrective actions have been put in place was also identified as a role of internal auditors. This was $77.5 \%$ of the responses gathered from the employees. This means that measures taken for corrects actions to be done are ensured by internal auditors.

Examining the reliability of accounting information was another role identified and it constituted $69.9 \%$ of the responses. Accounting information is very critical for all organizations so due to that, measures are to be put in place to ensure information produced is highly reliable. Hence, this implies that they play the role of ensuring that information provided by the banks is void of errors.

In addition, provision of consultations for top management relating to risk management as a role was identified which constituted $69.6 \%$ of responses and provision of consultations for top management in regard to sufficient internal control system also constituted $67.6 \%$ of the responses. These results confirm the definition of the Institute of Internal Auditors (2011c) "an independent, objective assurance and consulting activities made to add value and enhance an organization's operations.

More so, evaluation and improvement of effectiveness of risk management, control and governance processes 
was identified and constituted $64.7 \%$ of the responses. In effect, this suggests rural banks or organizations accomplish their objectives by coming up with a systematic, disciplined way to evaluate and enhance the effectiveness of risk management, control, and governance processes.

To review the systems used for safeguarding the company which constituted 56.8 percent was also a role identified by some employees. With this, internal audit ensures that, for example only budgetary items are honored. In this case, non - budgetary items are classified as illegitimate items which when honored might result in budget deficit. By this unplanned items or projects which are ignored by the aid of internal auditors make the administration of the banks or organizations safe.

According to Sarbanes-Oxley Act (2002), IA changed its emphasis to a compliance approach and Mihretet al. (2010) also reported that the role of IA in corporate governance has been strengthened after the Sarbanes-Oxley Act. This was confirmed in the study where compliance to policies, plans, procedures, laws and regulations was identified as another role of internal auditors and it constituted of 67.6 percent. This means in order to obey regulations, internal auditor should be up to task. It again confirms the assertion of Sarens \& De Beelde (2006) who posited internal auditors as 'policeman'/'watchdog' who operate in a more friendly manner, showing they are there to help improve internal control systems, by creating risk and control awareness on behalf of both the management and the board.

It can therefore be concluded that the roles of internal auditors as defined by IIA (2011c) are adhered to and known by employees.

\subsection{Perception on effectiveness of The Internal Audit Function}

In determining how well internal audit section is effective in their performance, the perceptions of people within the departments including internal auditors were obtained by questionnaire administered. All the departments were included so that there was no bias in assessing roles of internal auditors. This is found in Table 4.6.

Table 4.6: General Opinion Regarding the Internal Audit's Effectiveness

\begin{tabular}{|l|l|l|}
\hline Excellent $(\mathbf{9 0 \%} \mathbf{- 1 0 0 \% )}$ & Number of Responses & Percentage (\%) \\
\hline Moderate (70\%-89\%) & 49 & 15.69 \\
\hline Satisfactory (50\%- $\mathbf{6 9 \%})$ & 106 & 34.31 \\
\hline Not Good (blow 50\%) & 134 & 43.14 \\
\hline No response & 18 & 5.88 \\
\hline Total & 3 & 0.98 \\
\hline
\end{tabular}

Source: Field survey data, 2018

The table above indicated that $15.69 \%$ had a perception that the audit section effectiveness is excellent. These respondents opinion implies that audit section may have streamline some practices like procurement and compliance to standard accounting and auditing principles hence this help saved huge sums. Devoid of internal audit functions, the monies which are used for unplanned things to be purchased might have been fraudulently misused and also not accounted for. These responses meant internal audit section has streamline the financial controls by their routine audit inspections and frequent queries on any accounting practice that is not in line with accounting standards. Also, $34.31 \%$ showed that effectiveness of audit department was moderate. The responses from this category might suggest internal auditors discharging their roles well but can do better. Another category with the highest respondents was satisfactory group, $43.14 \%$ of respondents had perception that internal auditor work is satisfactory. Thus, this suggests that the employees of rural banks perceive effectiveness of an internal auditor to be acceptable, good and result oriented. The final two groups of respondents were no-response with 0.98 percent and not good with 5.9 percent meaning the most employees have perception that internal audit department is working well which probably yields results, however, there are few who have poor perception for internal auditors which could be as a result of roles of internal auditors in maintaining internal discipline and control in all functional aspect of the rural banks.

Finally it could be seen that greater respondents recognized effectiveness of internal auditors in the various rural banks. This implies that the roles internal auditors play are very effective and they are adding value to banks which support Yee et al. (2008) and Kibet (2008) who reported that internal audit function is effective and play a role in corporate governance. 


\subsection{Role of the Audit Committee In Relation to the Internal Auditor}

Table 4.7: Role of the Audit Committee In Relation to the Internal Auditor

\begin{tabular}{|c|c|c|}
\hline Roles of Audit Committee & $\begin{array}{l}\text { Number of } \\
\text { Responses }\end{array}$ & Percentage $(\%)$ \\
\hline Evaluate internal control systems & 258 & 83.3 \\
\hline monitor internal control systems & 70 & 22.5 \\
\hline Ensure risk management through its diligent oversight efforts & 137 & 44.1 \\
\hline ensuring reliable financial reporting & 88 & 28.4 \\
\hline strengthening internal audit as a profession & 237 & 76.4 \\
\hline to appoint the chief internal auditor & 237 & 76.5 \\
\hline $\begin{array}{l}\text { ensure that internal audit function operates accordingly to } \\
\text { professional standards }\end{array}$ & 283 & 91.2 \\
\hline provide an oversight of the corporate governance process & 271 & 87.3 \\
\hline $\begin{array}{l}\text { Good relationship between internal auditors and the audit } \\
\text { committee }\end{array}$ & 97 & 31.4 \\
\hline
\end{tabular}

Source: Field survey data, 2018

The second objective of this study was to identify roles of audit committee in relation to internal auditors in the rural banks in central region of Ghana. This was achieved by listing an excess of role of audit committee with the aid of literature for respondents to indicate Yes or No. In all, nine roles were identified for respondents to choose from. From the results, ensuring that internal audit function operates accordingly to professional standards was the most predominant response given as the role audit committee plays. This constituted $91.2 \%$ of the entire responses. Thus management of organizations set up audit committees so that work of internal auditors are done in a professional standard form. In effect, the committees absence could cause a mess as Pickett (2011) reported audit committee exists so that the internal auditing department can perform well and fulfil its responsibilities under audit plan and strategy.

Another important role identified was that, audit committee need to provide an oversight of corporate governance process which constituted $87.3 \%$. This responsibility of audit committee would make them have direct line to the shareholders; seek to ensure management is equipped to install effective risk management and controls within the company. Hence this is machinery for corporate accountability.

Members of audit committee need to have the skill, experience, and ability to asses and monitor internal control systems as according to Haron, 2012 was confirmed by the study results where roles of evaluation of internal control systems by audit committee was 83.3 responses and $22.5 \%$ for monitoring internal control systems. That of $22.5 \%$ for the monitoring implies few workers are aware of the fact that audit committee is meant to observe that internal control systems adhered to.

The appointment of chief internal auditor is done by audit committee. This role had $76.5 \%$ of the responses. This agrees with Pickett (2011) who reported that chief internal auditor is appointed by audit committee. In effect the result implies that in most organizations or rural banks, employees aware of this very role.

Furthermore, $76.4 \%$ of the responses said that audit committee's role is to strengthen internal audit as a profession. This suggests that effective audit committee ensures internal audit function will not only be a consulting activity but promoting internal audit function's independence (Mahzan et al., 2012).

Again, diligent oversight on risk management was identified by $44.1 \%$ responses. In risk management, audit committee need to see to it that negative risks are minimized and also proper risk assessment is done so that necessary control measures are put in place. Ensuring reliable financial reporting which comprised of $28.1 \%$ of responses was also confirmed as a role but with low response rate.

Good relationship between internal auditors and audit committee is necessary for effective internal control assurance and can in turn improve quality of financial statements (See Garc á et al., 2012). Although this role of audit committee was examine by the study but the response was very low. The role of ensuring good relationship between audit department and audit committee constituted $31.4 \%$ which depicts that the awareness of that role is low. Hence without ensuring good relationship, organization growth would be stagnant. 


\subsection{Challenges Facing Internal Auditors}

Table 4.8 Challenges Facing Internal Auditors

\begin{tabular}{|l|l|l|}
\hline Challenges & $\begin{array}{l}\text { Number } \\
\text { Responses }\end{array}$ & \multicolumn{1}{|c|}{$\begin{array}{l}\text { of } \\
(\%)\end{array}$} \\
\hline Intimidation and interference & 192 & 61.8 \\
\hline Indifferent attitude & 264 & 85.3 \\
\hline Inadequate Audit staff & & 49.0 \\
\hline Inadequate logistics & 264 & 85.3 \\
\hline Disregard to professional audit standards & 97 & 31.4 \\
\hline Prevention and detection of fraud & 264 & 85.3 \\
\hline Lack of independence & 228 & 73.5 \\
\hline Poor management support & 194 & 62.7 \\
\hline $\begin{array}{l}\text { Low level of cooperation between auditors and other employees } \\
\text { of the company }\end{array}$ & 216 & 69.6 \\
\hline Poor audit finding implementation. & & \\
\hline Sourc: Field survey data, 2018 & 261 & 84.3 \\
\hline
\end{tabular}

Source: Field survey data, 2018

In this section staffs of the banks were asked about the challenges internal auditors face when they are discharging their responsibilities. Data was analyses using multiple respondent techniques where several challenges were found. Inadequate logistics consisted of $85.3 \%$ of the responses. This could means that the offices of internal audit lack a number of logistics such as field recording accessories like laptops, cameras, portable scanners to capture spot data and observations as evidence to support documentations on financial improprieties. Also, poor audit finding implementation was another huge challenge. It implies that audit findings are normally not implemented, hence poor nature of work would persist and organizational growth cannot be materialized. This is in agreement of Mihretet al. (2010) who found out in Saudi Arabia that managers sometimes do not implement the recommendation of internal audit departments.

According to Barlow et al., (1997) it is the main responsibility of managers to prevent and detect frauds but managers do not, hence disregard this as their responsibility and expect the auditor to be responsible for the prevention and detection of fraud. This challenge was identified in the study confirming (Barlow et al., 1997) finding. In effect managers push that responsibility onto internal auditors which make their work load very huge and stressful.

Indifferent attitudes $85.3 \%$ and low level of cooperation between auditors and other workers of the company $69.6 \%$ were seen as another challenge disturbing internal auditors' responsibilities. This could imply that; other staff does not give the required support to internal auditors when they visit their department to work. It could also mean that most often heads of department expect that subordinates will hide secrets and shield deals in their department from the internal auditors. These challenges found support the findings of Bielińska-Dusza (2011) whose study took place in Poland, the study reported that lack of time, resistance of employees towards changes, organizational difficulties, information disturbances and work overload among auditors were challenges associated to internal auditors work.

Lack of independence accounting to $73.5 \%$ was identified by me as another challenge internal auditor's face in performing their duties. The duties or roles of internal auditors should be independence and objective but these are mostly compromised. This challenge makes internal auditors difficulty to perform its roles without partiality. This support Ahmad and Taylor (2009) which talks about challenges of internal auditors independence and their profession and has received renewed attention due to the rise of corporate governance.

In addition to the above challenges is accorded to poor management support which constituted $69.6 \%$. This indicates internal auditors are normally not supported by management because of possibly the corrupt nature of management. This might suggest internal audit is poorly funded and supported with the needed information. In the event of this, the work would be difficult for them and internal audit would be seen to be ineffective according to (Mebratu, 2012),

Inadequate audit staff constituting $49.0 \%$ which was relatively low was a challenge affecting internal audit in the rural banks. It could be seen from the department distribution that averagely one internal auditor mines an entire rural bank. This could make the work difficult for these few workers creating stressful situations for them. This could also imply that the inadequate staffing in audit department normally delays routine audit practices in the rural banks.

Intimidation and interference of work of internal audit staff was also discovered as a challenge. This constituted $61.8 \%$ of the responses. In effect, it suggests that other staffs that have internal control difficulties could hinder the operations of internal audit department. It might be that some employees personally frustrate internal auditors by physically preventing them from undertaking their audit activities. For example, an officer can 
intentionally decide not to come to work on a particular day if he knows the audit department will be there on that day. It might be that some employees even falsifies documents to cover up their misdeeds just to prevent internal audit staff who are able to identify fraudulent practice and does not support such standards from discharging their duties diligently.

An additional challenge with internal auditors discharging their roles is the disregard to accounting standards and practices accounting to $31.4 \%$. Although the percentage of responses is relatively small but it reflects the existence of the challenges in the rural banks. This suggests that most accounting standards at the rural banks are not done properly adhere to since supporting documents in some situations like receipts and invoices are not attached to the payment vouchers making auditing of such transactions very difficult. It could also mean that some protocols to follow as internal controls practices are not followed. For example, all items procured must be inspected by internal audit team to ensure they are in line with the specifications before they are sent to stores but unfortunately in most cases, it could be that items bought are rather sent to the stores and the supporting documents given to the finance office to effect payment.

\section{Conclusion}

Internal auditing in the rural banks is one of the very essential departments in the bank and as such if well managed could go a long way to improve the growth of the banks in Central region of Ghana. Data from the study revealed that all $(100 \%)$ of the rural banks have a well-established internal audit departments meant to assess compliance of management and to ensure maximum standards of good management practices.

The findings further indicate that internal auditors perform these roles: to appraise the effectiveness and efficiency of the resources employed; to evaluate the adequacy of company's system of internal control; to provide consultations for top management in regard to risk management; to be responsible for following up and ensuring the corrective actions are taken; to provide consultations for top management in regard to adequate internal control system and to examine the reliability of accounting information. These were the roles recognized by the respondents who were all employees of the rural banks in the region. These findings confirm exiting literature in the area of internal audit functions in business organizations and as such if internal auditors within the various rural banks are able to perform these duties in their line of work; their work will be effective and will improve on their profitability. But from the study it could be deduced that the perform some of the roles and leave others making their work not to be effective. Also it was discovered that the roles performed by audit committee in relations to internal auditors are: to provide an oversight of the corporate governance process; ensure that internal audit function operates accordingly to professional standards; to monitor internal control systems; to evaluate internal control systems; and to ensure risk management through its diligent oversight efforts; to appoint the chief internal auditor and ensuring reliable financial reporting. These findings supported literature like Garc á et al. (2012); Pickett (2011), whose work related to the roles of audit committee in corporate organization. Audit committee have an important role to perform to help internal auditors operate effectively as indicated by other school of taught, but when it does not take the pains to see to it that internal auditors are performing as expected of them and if they don't push their duties for management to perform for them which will intend make the work of internal audit in the rural banks difficult and ineffective. The study again identified that internal auditors face challenges such as: intimidation and interference; indifferent attitude; inadequate audit staff ; inadequate logistics; disregard to professional audit standards ; prevention and detection of fraud; lack of independence; poor management support; low level of cooperation between auditors and other workers of the company, and poor audit finding implementation. Hence the challenges identified facing internal auditors working in the rural banks in Central region of Ghana confirms the findings discovered by Bielińska-Dusza (2011); Mebratu (2012), Barlow et al. (1997) Ahmad and Taylor (2009) in similar studies. Internal auditors are to help and eliminate risk and losses that might be facing the banks, but if their needs and support needed by them to work is lacking then the bank will be at a lost. From the research it was noted that this challenges are still persisting and affecting internal auditors in the rural banks which is making them ineffective. Again, the research found that the recommendations that are made by internal audit department are not always implemented by management, and audit committee does not do follow ups on the recommendation to see if they are implemented by management. This gives the implication that some banks are still not efficient due to poor implementations of internal audit findings. On a general ground in relation to the research work, effectiveness of internal audit in the rural banks in central region was rated as satisfactory

\subsection{Recommendations}

Base on the findings of the research established herein, the study recommends that an In-service training and other short courses should be organized for internal auditors at the rural banks to update their knowledge and skills on the modern trend in carrying out auditing activities. This will help put them in a better position to overcome challenges of modern internal audit. Second, audit committee endeavor to seeing to it that recommendations made by internal auditors are implemented to the root and some not left hanging and unresolved. Again, board of 
directors must ensure that the wealth of the shareholders are been protected by seeing to it that audit committee addresses all concerns address by internal auditors. Lastly, internal auditors need to be well motivated to increase their effort on the job, so as to work with some sense of accomplishment and accountability. By this, the internal audit department should also focus on risk as it's also an integral part of their work and if done well this can increase the productivity of their banks.

\section{References}

Addo, J. S. (1998). "A Feasibility Study and Business Plan for the Establishment of an ARB Apex Bank," Accra: revised report for the Association of Rural Banks.

Ahmad, Z. and Taylor, D. (2009) "Commitment to independence by internal auditors: the effects of role ambiguity and role conflict independence" Managerial Auditing Journal, Vol.24 pp.899-924

Al-Twaijry, A. A. M., Brierley, J. A. \& Gwilliam, D. R. (2004), "An Examination of the Relationship Between internal and external audit in the Saudi Arabian corporate sector": Managerial Auditing Journal, 19 (7), pp.929-45. And Management, vol. 34, no. 5, pp. 529 -541

Al-Twaijry, A.A.M., Brierley, J.A. and Gwilliam, D.R. (2003), "The development of internal audit in Saudi Arabia: an institutional theory perspective", Critical Perspectives on Accounting, Vol. 14 No. 5, pp. 507-31.

Anin, T. E. (2000). Banking in Ghana, Accra: Woeli Publishing Services.

Arena, M. and Azzone, G. (2007) "Internal Audit Departments: Adoption and Characteristics in Italian Companies", International Journal of Auditing, vol. 11, no. 2, pp. 91 -114.

Arena, M. and Azzone, G. (2009), "Identifying organizational drivers of internal audit effectiveness", International Journal of Auditing, Vol. 13 No. 1, pp. 43-60.

Asiedu-Mante, E. (2011). Rural Banking in Ghana.Accra, Ghana: Combert Impressions Limited.

Bank of Ghana, (2014). "Bank of Ghana: Licensed Banks, Representative Offices and Their Registered Offices in Ghana As At December 2013". Bank of Ghana (BOG). Available at: http//www.bog.gov.gh/index.php?option-com_content\&rview=articles\&id-82\&itemid=124. Date: 4 September 2015.

Barlow, P., Helberg, S., Large, N. \& Le Roux, K. (1997). The Business Approach to Internal Auditing. Second Edition. South Africa: Juta

Bell, E., \& Bryman, A. (2007). The ethics of management research: an exploratory content analysis. British Journal of Management, 18(1), 63-77.

Bielińska-Dusza, E. (2011), Analysis of Internal Audit Functioning in Poland - Empirical Research Findings. Business, Management and Education 9(2):236-247. http://dx.doi.org/10.3846/ bme.2011.16

Bielińska-Dusza, E. (2011), Analysis of Internal Audit Functioning in Poland - Empirical Research Findings. Business, Management and Education 9(2):236-247. http://dx.doi.org/10.3846/ bme.2011.16

Bou-Raad, G. (2000), "Internal auditors and the value added approach: the new business regime", Managerial Auditing Journal, Vol. 15 No. 4, pp. 183-6.

Darko, S., Terkper, V. D., Novixoxo, J. D., \& Anning, L. (2018). Assessing the Effect of Lead Time Management on Customer Satisfaction.

Davidson, R., Goodwin-Stewart, J. \& Kent, P. (2005), "Internal Governance Structures and Earnings Management", Accounting and Finance, 45(2), 241-67

DiMaggio, P. J. and Powell, W. W. (1983), "The iron cage revisited: institutional isomorphism and collective rationality in organizational fields ", American Sociological Review Vol. 48 No. 2, pp. 147-160.

Enyue, Z. (1997), "Development trends of internal auditing in China”, Managerial Auditing Journal, Vol. 12 Nos $4 / 5$, pp. $205-9$.

Fogarty, T. and Rogers, R. (2005). Financial analysts' reports: an extended institutional theory evaluation. Accounting, Organizations and Society, 30 (4)331-356.

Fogarty, T. J. (1996), 'The imagery and reality of peer review in the US: insights from institutional theory', Accounting Organizations and Society 21: 243-68.

García, L. S., Barbadillo, E. R. and Pérez, M.O. 2010. "Audit committee and internal audit and the quality of earnings: empirical evidence from Spanish companies", Journal of Management and Governance, vol. 16 , no. 2 , pp. $305-331$.

Goodwin, J (2003), 'The relationship between the audit committee and the internal audit function: Evidence from Australia and New Zealand', International Journal of Auditing, vol. 7, no. 3, pp. 263-78

Goodwin, J. (2004), “A comparison of internal audit in the private and public sectors", Managerial Auditing Journal, Vol. 19 No. 5, pp. 640-50.

Haron, M. S. B., Idiab, A. I. M. \& Ahmad, S. B. H. 2012. "Total quality management and its relationship with the internal audit", Australian Journal of Basic and Applied Sciences, vol. 6, no. 9, pp. 660-668.

Hass, S., \& Abdolmohammad, M., Burnaby, P. (2006a), “A review of prior common body of knowledge (CBOK) studies in internal auditing and an overview of the global CBOK 2006”. Managerial Auditing Journal, 21 (8), 
$811-821$

Hass, S., Abdolmohammadi, M. J \& Burnaby, P. (2006b), 'The Americas literature review on internal auditing', Managerial Auditing Journal, 21 (8) 835-44.

Huq, M. M. (1989), The Economy of Ghana: the first 25 years since independence. Macmillan.

Institute of Internal Auditors (2010), "Global Internal Audit Survey, Nine Elements Required for Internal Audit Effectiveness in the Public Sector". Research Report. The Institute of Internal Auditors Research Foundation (IIARF), Florida.

Institute of Internal Auditors Belgium. (2006), " Internal Audit in Belgium: The Shaping of Internal Audit Today and the Future Expectations -Survey Results", Available at: http://www.iiabel.be/ Date: 8 August 2015

Jensen, M. C. (2000). A Theory of the Firm: Governance, Residual Claims and Organizational Forms. Harvard University Press, Journal of Financial Economics (JFE), 3(4). Retrieved from SSRN: http://ssrn.com/abstract $=94043$ or DOI: $10.2139 /$ ssrn. 94043

Keitany, J.L. (2000), "The Internal Audit control function and its implication for risk assessment by the external auditor": A case of quoted companies. Unpublished MBA Project, University of Nairobi.

Kibet, P.K. (2008). A survey on the role of internal audit in promoting good corporate governance in SOEs. Unpublished MBA Project, University of Nairobi.

Kwon, I.W.G. \& Banks, D.W. (2004) 'Factors related to the organizational and professional commitment of internal auditors', Managerial Auditing Journal, vol. 19, no. 5, pp. 606-22.

Mahzan, N., Zulkifli, N., \& Umor, S. 2012. "Role and Authority: An Empirical Study on Internal Auditors in Malaysia", Asian Journal of Business and Accounting, vol. 5, no. 2, pp. 69 -98

Mebratu, A. A. (2012), Challenges of Internal Audit Function In Public Sector Governance: Empirical Evidence From Ethiopia. International Journal of Research in Computer Application \& Management. 2(11) 23-33.

Meckling, W. H., \& Jensen, M. C. (1976). Theory of the Firm: Managerial Behavior, Agency Costs and Ownership Structure.

Meyer, J. \& Rowan, B. (1977) 'Institutional Organizations: Formal Structure as Myth and Ceremony', The American Journal of Sociology. 83, (2) 340-63.

Mihret, D. G., \& Woldeyohnnis, G. Z. (2008) Value-add role of internal audit: An Ethiopia Case Study. Managerial Auditing Journal, 2(6), 567-595

Mitnick, B.M. (2006). Origin of the Theory of Agency: An Account by One of the Theory's Originators. Retrieved from SSRN: http://ssrn.com/abstract=1020378 (20th October, 2015)

Moeller, R. (2005), Brink's Modern Internal Auditing, John Wiley \& Sons, Hoboken, NJ.

Nair, A. and Fissha, A. (2010), Rural Banking: The case of rural and community banks in Ghana. Agriculture and Rural Development Discussion Paper 48. The World Bank. Washington DC.

O Leary, C \& Stewart, J. (2007), Governance Factors Affecting Internal Auditors ${ }^{e e}$ Ethical Decision-Making: An Exploratory Study", Managerial Auditing Journal, 22 (8), 787 - 808

Pickett, K. H. S. (2011) The essential guide to internal auditing. (2nd edition) Chichester: John Wiley \& Sons Ltd

Ramachandran, J., Subramanian, R. and Kisoka, J. I. (2012) Effectiveness of Internal Audit in Tanzanian Commercial Banks. British Journal of Arts and Social Sciences 8 (1)32-44

Roth, J. (2000), Best Practices: Value-added Approaches of Four Innovative Auditing Departments, The Institute of Internal Auditors Research Foundation, Altamonte Springs, FL.

Roth, J. (2002), Adding Value: Seven Roads to Success, The Institute of Internal Auditors Research Foundation, Altamonte Springs, FL.

Sarens G. \& Beelde I.D. (2006) "“ The Relationship between Internal Audit and Senior Management, A Qualitative Analysis of Expectations and Perceptions ": International Journal of Auditing ,10(3), 219 41

Sarens, G. \& De Beelde, I. (2006), A comparison between US and Belgian companies", Managerial Auditing Journal, 21 (1) 63-80.

SOX (2012) The Sarbanes - Oxley Act (SOX) of 2002 Pub. L. 107 -204, 116 Stat. 745, enacted July 30, 2002. United States federal law.

The Institute of Internal Auditors (IIA), 2012b. “The Audit Committee: Internal audit oversight”. Altamonte Springs, Florida.

Yee, R.W.Y., Yeung, A.C.L., \& Cheng, E. T. C., (2008) The impact of employee satisfaction on quality and profitability in high-contact service industries. Journal of operations Management. 26 (651-668) 